\title{
The Impact of Balai Sakinah 'Aisyiyah Programs on Increasing Women Empowerment
}

\author{
Eko Kurniasih Pratiwi ${ }^{1, *}$ Istania Widayati ${ }^{2}$
}

\author{
${ }^{I}$ Department of Islamic Economics Law, Universitas Muhammadiyah Magelang, Magelang, Indonesia \\ ${ }^{2}$ Department of Islamic Education, Universitas Muhammadiyah Magelang, Magelang, Indonesia \\ *Corresponding author. Email: ekokurniasihpratiwi@ummgl.ac.id
}

\begin{abstract}
Women empowerment is an essential goal in achieving sustainable development worldwide. In 2016, however, Indonesia ranked 105 out of 159 countries in the Gender Inequality Index. It indicates that women's leadership capacity and gender equality in Indonesia must be improved. Balai Sakinah 'Aisyiyah (BSA) is a leading program of 'Aisyiyah which aims to increase women's independence to be more empowered. This study aims to find out the implementation of Balai Sakinah 'Aisyiyah programs and uts impact on increasing women's empowerment. The research method used a descriptive exploratory approach with in-depth interviews. The result shows that the BSA Programs had various activities, including public health, reproduction, economics, and religious affairs. Through the BSA, the community is also educated to advocate the formulation of village government's policies that accommodate women's concerns. The activities carried out by the BSA program have been able to improve the quality of women in terms of economics, religious affairs, and health. It implies that the program is recommended to become a broad women empowerment program.
\end{abstract}

Keywords: empowerment, women, Balai Sakinah Aisyiyah

\section{INTRODUCTION}

The Sustainable Development Goals declare no poverty as the first point of the priority. This means that the world has agreed to eliminate poverty in any form throughout the world, including Indonesia. Poverty alleviation will be very much linked to other global goals, namely a world without hunger, but with good health and well-being, good education, gender equality, clean water and sanitation, clean and affordable energy, etc., and thus, partnerships is important to achieve these goals [1].

Women in Indonesia are vulnerable to poverty. Indonesia ranks 105 out of 159 countries in the 2016 Gender Inequality Index. Compared to men, women are still lagging in terms of work participation, political participation, and educational attainment. Progress in gender equality and women empowerment is increasingly recognized as an important part of inclusive economic growth and development [2]. Moreover, Women with better levels of empowerment will have a lower chance of experiencing infant mortality. This emphasizes the importance of empowering women to reduce the number of infant mortality [3].

The success of SDGs is closely related to the important role of local government because the local governments (a) are closer to their citizens; (b) has authority and funds; (c) can make various innovations, and (d) are the spearhead of public service providers and various government policies and programs. From the experience of the MDGs era (2000-
2015), Indonesia has not succeeded in reducing maternal mortality, increasing good sanitation and drinking water, and decreasing the HIV/AIDS prevalence. Investments in women's empowerment through education, health and economic empowerment will be able to improve the quality of women's lives. The implication that will be obtained is the birth of a superior successor generation of the nation and a better social life. [4]. There have been many women's empowerment programs carried out, such as providing soft loans to poor women [5] in economic sector. A growing number of leading companies agree that women not only have the right to achieve their full economic potential, ensuring they do so is essential to business innovation, productivity, risk management, and market growth.[6] In 2012, the Australian and Indonesian Government initiated the formation of collaborative programs for Gender Equality and Women Empowerment, better known as MAMPU. MAMPU supports the achievement of the National Medium-Term Development Plan (2015-2019 RPJMN) and the Sustainable Development Goals (TPB) by increasing the access of poor women to basic government services and programs. MAMPU achieves this by developing women's collective capacities and empowering them to influence decision making at the village level to the national level. MAMPU has partnered with civil society organizations that advocate for women's issues - called as MAMPU partners - that cooperate with the government, parliament and the private sectors. This network has an important role in reforming the government for the benefit of poor women.

MAMPU is working with 14 women's organizations to carry out various programs planned during 2012-2020. By involving poor women and community leaders directly, MAMPU works to increase demand and provide better basic services. Through advocacy, by and on behalf of poor 
women, MAMPU influences changes in government policies and budgeting to improve the quality and provision of these services. One of the women's organizations that is in partnership with MAMPU is "Aisyiyah. "Aisyiyah is the first women's organization in Indonesia which currently has 33 'Aisyiyah Provincial Leadership level, 370 'Aisyiyah Regional Leadership level, 2,332 "Aisyiyah District Leadership level, and 6,924 "Aisyiyah Village Leadership Level. 'Aisyiyah as autonomous organization plays a significant role in building the quality of Islamic women in Indonesia. [7]

'Aisyiyah's role in fostering a sakinah family is manifested in a variety of coaching consisting of fostering of religious aspects, educational aspects, health aspects, economic aspects, and social aspects. The coaching is carried out through a work program that is owned by 'Aisyiyah's management structure at all leadership level [8]

One of MAMPU programs run by Aisyyah is the Balai Sakinah "Aisyiyah (BSA) program. BSA is an extension of the Qoryah Tayyibah program which was first implemented in all 'Aisyiyah village branches throughout Indonesia. This study aims to determine the impact of the Balai 'Aisyiyah Sakinah program to increase women empowerment.

The BSA program is still implemented by some village leadership level of 'Aisyiyah, has not yet been implemented by all of 'Aisyiyah branches in Indonesia. Discussion on the BSA program's contribution to women empowerment is expected to provide evaluation and input for related parties.

\section{RESEARCH METHODS}

This research was a descriptive analysis that begins with a search of the most recent references about the objectives, benefits and guidelines for the implementation of the Balai 'Aisyiyah Sakinah Program at the level of 'Aisyiyah Central Leadership, 'Aisyiyah Provincial Leadership and 'Aisyiyah Regional Leadership. The next stage is creating the instruments and indicators of the achievement of the Balai Sakinah 'Aisyiyah's programs that were used to describe, test and analyze the data. Then, in the third stage, the data supporting the analysis were collected through observation, documentation, and in-depth interviews through FGD (Forum Group Discussion) with respondents. The data obtained were then analyzed and compared by using the theories and related regulations to find out the appropriateness of the principles between the applicable theories and activities in the field.

Data collection techniques:

a. Observation was used to collect the data about the implementation of the Balai Sakinah 'Aisyiyah program carried out by the 'Aisyiyah Regional Leadership that received MAMPU program grant.

b. Interview was used to collect the data on research subjects and informants related to the activity profile, access to activities and control over the resources and benefits obtained, the influencing factors and analysis of the 'Aisyiyah Balai Sakinah program cycle. Interviews were conducted with the MAMPU Team and the BSA Cadres in Magelang Regency c. Documentation was used to get information about Balai Sakinah "Aisyiyah activities through reports and news from website pages.

d. Forum Group Discussion was used to collect qualitative data on programs that have been implemented by the MAMPU Team of Balai Sakinah 'Aisyiyah. The FGD was conducted with BSA participants.

\subsection{Data Analysis}

After the data were collected, it was then edited and sorted. Qualitative data was collected by FGD, observation, and interview. An interactive data analysis model is possible when researchers are in the field. The analysis was done descriptively. Qualitative research allowed within site analysis and after site analysis.

Then, data reduction was made based on the relevance and adequacy of information to explain the profile of activities, access to activities and control over resources and benefits, influencing factors and the analysis of the "Aisyiyah Balai Sakinah program cycle.

Data reduction in this study essentially simplified and systematically compiled the data in the dimensions of the process and the utilization of assets. The results of the data reduction were then presented in the form of a data display. Narrative descriptions were used to present the data. The next step was a conclusion and or verification making. In this model, there was an interactive relationship between the main components in the analysis. Therefore, in this study, verification was conducted by looking back at the data reduction and data display so that the conclusion did not deviate from the analyzed data. The flow is as follows:

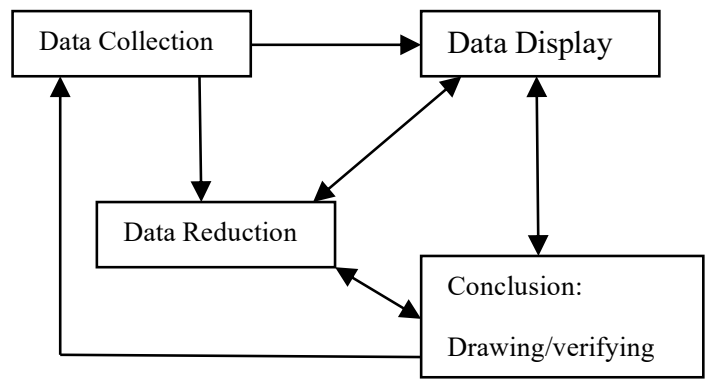

Figure 1 Data Analysis Techniques

\section{RESULTS AND DISCUSSION}

\subsection{The Description of Balai Sakinah 'Aisyiyah Program}

The Balai Sakinah 'Aisyiyah (BSA) of 'Aisyiyah Regional Leadership (henceforth called as PDA) Magelang Regency was formed in February 2016 and started its activities in March 2016. BSA is one of the embodiments of the MAMPU grant obtained by the PDA Magelang District. The MAMPU program is a program that thematically 
focuses on women's health, but can be developed into other fields.

In general, the purpose of the Thematic MAMPU Women's Health program is Strengthening Women's Leadership to Improve Women's Health and Nutrition Status, while the objective of MAMPU program of 'Aisyiyah itself is the Fulfillment of Basic Rights for Women's Reproduction Health Dhu'afa Mustadh'afin.

The specific goal of the MAMPU program is the realization of a women community that have an awareness of reproduction health rights, the realization of a ta'awun community that helps each other to realize the fulfillment of reproduction health rights and the realization of community empowerment (productive economy, productive family management, child nutrition, environment, sanitation, food security). Balai Sakinah 'Aisyiyah as a manifestation of MAMPU program accommodates the objectives as stated in the MAMPU program.

Themes or issues raised by 'Aisyiyah through the MAMPU program are:

a. Reproduction health, especially related to early detection of cervical cancer and breast cancer.

b. Exclusive breastfeeding program and continued until 2 years by giving certificates to mothers who successfully carry out the program

c. Nutrition Program, especially related to stunting prevention.

d. Participation in National Health Insurance, Family Planning, Child Marriage, violence against women and children, Women's Empowerment, Women's Participation in Musrenbang, and women's issues in rural development.

e. Women's Economic Empowerment

\subsection{Activities and Contribution of Balai Sakinah Aisyiyah program}

In general, the MAMPU program initiated by the "Aisyiyah Central Leadership has the ultimate goal in the realm of women's leadership and gender equality. However, the reality faced in society, the stage of women's leadership which means women's independence in the public sphere is still far from ideal. The stigma regarding women as only a domestic partner of men is a limitation for women to improve their knowledge and skills to realize their independence. For this reason, the establishment of Balai Sakinah 'Aisyiyah as the first step toward women's independence is appropriate. It is because the BSA refers to regions with unique characteristics and the selection of programs and activities is adjusted to the character of each region so that it is more easily accepted and based on community needs. This, for example, is reflected in the selection of locations, which is in Kalibening and Mangli. The two regions have different characteristics. Kalibeling is a fairly advanced society, with a better level of education. Open village leadership provides a great opportunity for BSA cadres and activists to be developed. This is proven by the disbursement of Village Government funds that have been specifically allocated to improve the quality of women in the Kalibening, either through IVA tests or other programs. Unlike in Kalibening, Mangli which is an agricultural area has lower level of education. The BSA's activities initially focus more on general health and how to improve the agricultural crops as the main sector of the Mangli community.

Some of the activities carried out in the Balai Sakinah 'Aisyiyah program series which are published on website are as follows:

First, a group of women farmers who are members of Balai Sakinah 'Aisyiyah (BSA), Mangli Kaliangkrik Branch, held an Organic Agriculture Training activity on Thursday in the village of Mangli, Kaliangkrik, Magelang Regency. Participants in organic agriculture training included the Head of the Mangli hamlet, cadres and members of Balai Sakinah Balai Aisyiyah Mangli, the Regional Economic Leadership Council 'Aisyiyah Magelang Regency and the MAMPU program management team (advancing Indonesian women for poverty reduction). This training is also an effort of the "Aisyiyah Regional Leadership Magelang Regency to empower women through organic farming, which in turn will produce superior agricultural products of Asiyiyah Mangli, Kaliangkrik [9].

Next, the discussion on reproduction health in the Balai Sakinah 'Aisyiyah program provides information to women in Indonesia who have never had access to watch television or read printed media to find out the reproduction health and carry out IVA Tests [10].

Last, the cadre of Balai Sakinah 'Aisyiyah has a high awareness and enthusiasm of struggle to provide education to women around her for reproduction health, clinical breast examinations, and visual inspection tests for acetic acid (IVA) [11].

The programs and activities carried out by BSA have positive impact on improving the quality of women in some aspects, namely:

First, there is an improvement of women's knowledge and understanding of reproduction health, particularly related to cervical cancer and breast cancer, which are the first and second death trigger in Indonesia. Furthermore, it improves the awareness to take IVA and clinical breast test (sadarnis) to detect early illness so that the quality of women's health through this program is continue to be better.

Second, the programs also improve the spiritual quality of BSA members. This relates to the existence of BSA as one of the programs of 'Aisyiyah, one of the Muhammadiyah autonomous organization, which suggests religious content in every program or activity.

Third, it increases the public capability of women. It can be seen from the development of BSA's organizational leadership, public speaking and managerial organizational skills that have increased both in quantity and in quality. Fourth, the programs are able to increase the economic capacity and empowerment. The BSA's programs that has been carried out has been proven to be able to increase economic productivity for women, for example by increasing the production of snacks in Kalibening, Mangli tea and various chips in Mangli. 


\section{REFERENCES}

[1] S. T. R. I. Raharjo, 'Sustainable Development Goals ( SDGs )', vol. 42, pp. 159-167, 2015.

[2] MAMPU, Kemitraan Australia-Indonesia untuk Kesetaraan Gender dan Pemberdayaan Perempuan, vol., no. Id. 2020.

[3] H. Stiyaningsih and F. Wicaksono, 'Impact of Women's Empowerment on Infant Mortality in Indonesia', Kesmas Natl. Public Heal. J., vol. 11, no. 4, p. $185,2017$.

[4] F. Hasin, 'Women Empowerment Model: Strategies to Overcome Challeges', J. Fundam. Appl. Sci. ISSN, no. January, 2016.

[5] J. Ali and R. Abdul-hakim, 'The Impact of Microcredit Program on Women Empowerment : Evidence from T HE I MPACT O F M ICROCREDIT P ROGRAM O N W OMEN', no. May 2014, 2012.

[6] I. BSR, 'Building Effective Women's Economic Empowerment Strategies', 2016.

[7] P. Suyaman, L. Siwiyanti, and Y. S. Wahyuni, 'Condition of Branches and Subsections as well as Charitable Enterprises of the Aisyiyah Autonomous Organization in Sukabumi Regency', Int. J. Humanit. Soc. Sci. Educ., vol. 4, no. 4, pp. 104-108, 2017.

[8] R. Adawiah, 'Aisyiyah dan Kiprahnya dalam Pembinaan Keluarga Sakinah', J. Stud. Gend. dan Anak, vol. 1, no. 2, pp. 97-116, 2013.

[9] P. P. Muhammadiyah, 'Balai Sakinah 'Aisyiyah Kaliangkrik Kembangkan Pertanian Organik', www.umm.ac.id, 2018. [Online]. Available: http://www.umm.ac.id/id/muhammadiyah/15014.html.

[10] no name, 'Nur: Balai Sakinah 'Aisyiyah, Sumber Informasi bagi Perempuan', http://www.mampu.or.id/cerita-perubahan/foto/nurbalai-sakinah-aisyiyah-sumber-informasi-bagiperempuan/, 2015. [Online]. Available: http://www.mampu.or.id/cerita-perubahan/foto/nurbalai-sakinah-aisyiyah-sumber-informasi-bagiperempuan/.

[11] A. Sasongko, 'Kisah Relawan Balai Sakinah Aisyiyah Cegah Kanker', www.khazanah.republika.co.id, 2019.
Conceptualization (E.K.P); Material research preparation (I.W); Methodology (E.K.P, I.W); Data collecting (E.K.P, I.W); Data analysis (E.K.P, I.W); Writing — original draft (E.K.P); Presentation (E.K.P). 